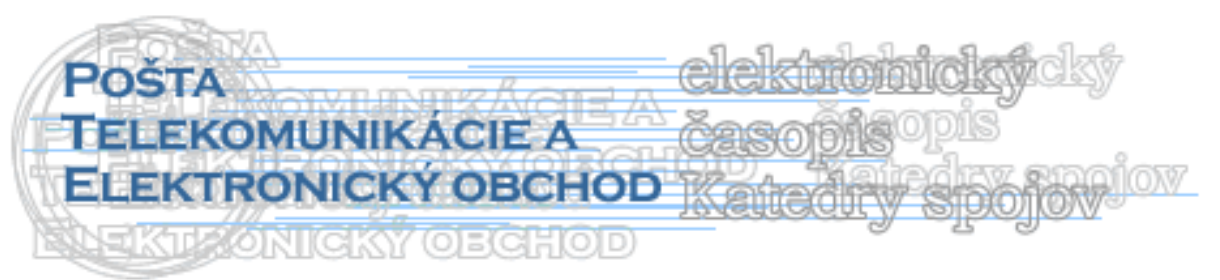

\title{
VIRTUÁLNY PROJEKTOVÝ MANAŽMENT - MODEL ATRIBÚTOV PROJEKTOVÉHO MANAŽÉRA
}

\author{
Jozef Fabuš*, Iveta Kremeňová*
}

\section{Úvod}

V dnešnom svete plnom rozvoja informačných technológií je možné vytvárat' projektové tímy bez potreby fyzického kontaktu. V určitých prípadoch je nutné, aby na projekte pracovali členovia tímu z rôznych zahraničných lokalít. Vznikajú tak kultúrne a jazykové bariéry, ktoré musí riešit' projektový manažér.

Pre správne fungovanie virtuálnych projektových tímov je pre manažéra potrebné mat' iné vlastnosti ako pre projektového manažéra tímov komunikujúcich tvárou v tvár. Problémy tradičného projektového manažéra sú rozdielne od virtuálneho. Tradičné atribúty manažéra: plánovanie, organizovanie, koordinácia, riadenie a kontrola manažér musí ovládat', ale pri zameriavaní sa na jednotlivé zložky atribútov, musí zvažovat' kultúrne, časové a fyzické paradoxy, ktoré sa od tradičného projektového manažéra nepožadujú.

\section{Atribúty manažéra}

Základnými funkciami manažmentu sú plánovanie, rozhodovanie, organizovanie, vedenie l’udí a kontrola. Atribúty manažéra vychádzajú so základných funkcií manažmentu. Oproti funkciám je pri atribútoch zmena, rozhodovanie je označované ako koordinácia a vedenie l'udí ako riadenie.

- $\quad$ * Ing. Jozef Fabuš., Žilinská Univerzita v Žiline, katedra spojov NF300,

- $\quad$ tel.: +421917420903

- e-mail: jozef.fabus@postfpedas.uniza.sk

- * Doc. Ing. Iveta Kremeňová., Žilinská Univerzita v Žiline, katedra spojov NF450,

- e-mail: iveta.kremenova@postfpedas.uniza.sk 
Atribúty manažéra, znázornené v obrázku 1, sa vetvia na jednotlivé činnosti v oblastiach základných funkcií manažmentu:

- Plánovanie

$$
\begin{aligned}
& \text { - definovanie ciel’ov, } \\
& \text { ○ plán činností, } \\
& \text { ○ komunikačný plán. }
\end{aligned}
$$

- Organizovanie
○ identifikácia zdrojov,
- nastavenie štandardov,
○ organizačná štruktúra.

- Kontrola
○ monitorovanie výkonov,
- vzdelávanie, odmeňovanie a disciplína,
- komunikácia,
○ spätná väzba

- Riadenie
○ stimulácia záujmov,
- motivácia,
- tím building,
○ building jednotlivcov.

- Koordinácia

○ riešenie konfliktov

○ Kooperácia.

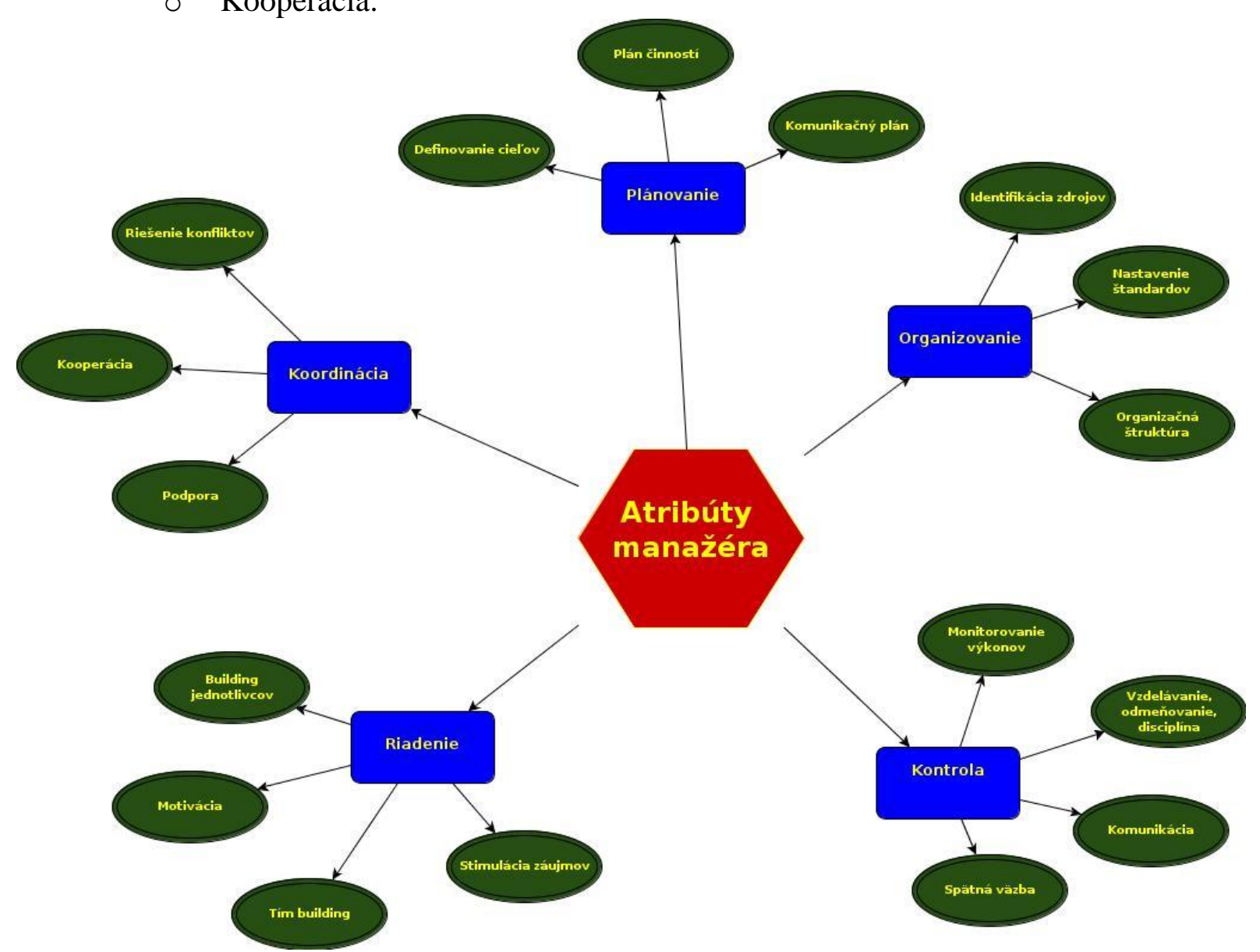

Obrázok 1: Atribúty manažéra projektu

(zdroj: vlastné vyhotovenie) 


\section{Virtuálny projektový tím}

Vývoj informačných technológií a služieb je technická oblast', ktorá je vhodná pre tímy, ktorých členovia sa nenachádzajú na rovnakom mieste. Nazývajú sa virtuálne tímy. Virtuálne tímy a sú zložené s členov tímu, ktorí sú rozmiestnení na rôznych miestach. Členovia tímu môžu pracovat' $\mathrm{z}$ domu, v inom meste alebo dokonca aj v zahraničí. Sloboda práce na dial'ku má výhody pre zamestnancov aj organizáciu.

\section{Výhody práce na dial'ku:}

- Vysoká oblúbenost' medzi zamestnancami - pracujú na projekte a sú pracujú v známom prostredí,

- Nižšie náklady na podnikanie - šetrenie na kancelárskych priestoroch, náklady sa nezvýšia zamestnancovi, ked’že za domácnost' platí vždy,

- Prístup k viacerým talentom - širšia oblast', prístupné talenty z celého sveta,

- Zamestnanci majú pružnú pracovnú dobu, aby dokončili úlohy, vol'nost' je u zamestnancov obl'úbená,

- Zamestnanci nestrácajú čas cestovaním do práce - viac času na prácu,

- Pomáha prostrediu, zamestnanci sú doma a nepoužívajú autá, alebo iný druh prepravy. Virtuálny projektový tím prináša nevýhody hlavne v oblasti komunikácie. Manažér mat' iný rozloženie atribútov ako pri tradičných tímoch.

\section{Atribúty manažéra virtuálneho tímu}

Virtuálny projektový tím prináša nevýhody v oblasti komunikácie. Manažér mat' iný rozloženie atribútov ako pri tradičných tímoch. Pozornost' si pýta aj rozdielnost' časových pásiem, v prípade zahraničnej spolupráce.

\section{Plánovanie:}

Plánovanie je dôležité aj pri virtuálnych projektových tímoch. Na rozdiel od tradičného manažéra, virtuálne tímy potrebujú špeciálnu starostlivost'.

Definovanie ciel'ov

Definícia ciel'ov je rovnaká ako pri tradičnom manažmente. Manažér musí naštudovat' projekt a následne definovat' ciele podl'a potrieb. Správny manažér vidí aj skryté ciele, ktoré v dokumentácií zadávania projektu nenájde. Odporúča sa komunikovat' zo zadávatel'om pre zistenie bližších špecifík projektu.

\section{Vytvorenie tímu}

Pri plánovaní tradičného projektového tímu sa plánujú činnosti a podl'a činností sa určia pozície potrebné ku kvalitnému vypracovaniu projektu. Pri virtuálnom projektovom manažmente je potrebné ako prvé vybrat' tím. Časový posun môže spôsobit' nepríjemné problémy a pri zahraničných spolupracovníkoch sa vyskytuje častejšie. Manažér musí rátat' s kultúrnymi problémami, sviatky ktoré slávi manažér projektu, ktorý je z Európy, sa môžu značne líšit' od sviatkov, ktoré slávi člen tímu v Ázii.

\section{Plán činností}

Naplánovat' činnosti virtuálneho projektu je zložitejšie, do úvahy manažér musí vziat' jednotlivých členov tímu, prvý dopad časového posunu na projekt. Manažér musí rátat' s istým oneskorením. Náboženské a kultúrne vplyvy ovplyvňujú naplánovanie činností. Plánovat' činnosti pred identifikovaním tímu je nevhodné.

\section{Komunikačný plán}

Najväčším problémom plánovania projektu plneného virtuálnym tímom je komunikačný plán. Manažér musí naplánovat' on-line mítingy v čase vhodnom pre všetkých 
členov tímu. Časové vyt'aženie manažéra je tým vyššie, čím sú členovia tímu od seba viac vzdialení. Manažér musí rátat's časovým posunom u každého člena tímu.

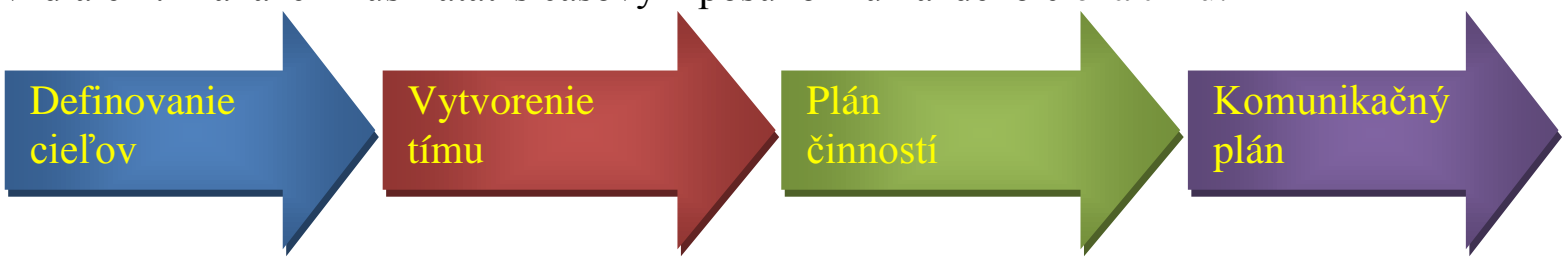

Obrázok 2. Kroky plánovania manažéra virtuálneho tímu

\section{Organizovanie:}

(Zdroj: vlastné spracovanie)

Organizovanie pri virtuálnych tímoch je zložitejšie. Dôležitá informácia pre manažéra pri rozhodovaní byt' poctivý a vyberat' členov podl'a kvality. Žiadny projektový manažér nesmie diskriminovat' národnosti a menšiny.

Identifikácia zdrojov

Organizovat' projekt pre manažéra znamená poznat' prostriedky, ktorými môže disponovat', prípadne ktoré môže získat' ich zmenou. (finančné na hmotné a pod.) Rozdiel oproti tradičnému manažmentu je v alokácii majetku. Sprístupnenie softvéru je možné aj na vel'kú vzdialenost' bez finančných problémov, posielat' hardvér alebo iný hmotný majetok, vyžaduje zvýšené náklady.

Nastavenie štandardov

Rovnako ako pri tradičnom projektovom manažmente, nastavit' štandardy, ktoré uzákonia minimálne požiadavky na výkon jednotlivých členov tímu.

Organizačná štruktúra

Pri organizačnej štruktúre virtuálneho tímu je dôležitý faktor ovplyvňujúci podvedomie vedúceho tímu. Francúz podradený Angličanovi bude vykazovat' zníženú kvalitu výkonov, kvôli vrodenej nevraživosti. Náboženské rozdiely spôsobujú mnoho d'alších problémov. Manažér musí poznat' dokonale celý svoj pracovný tím.
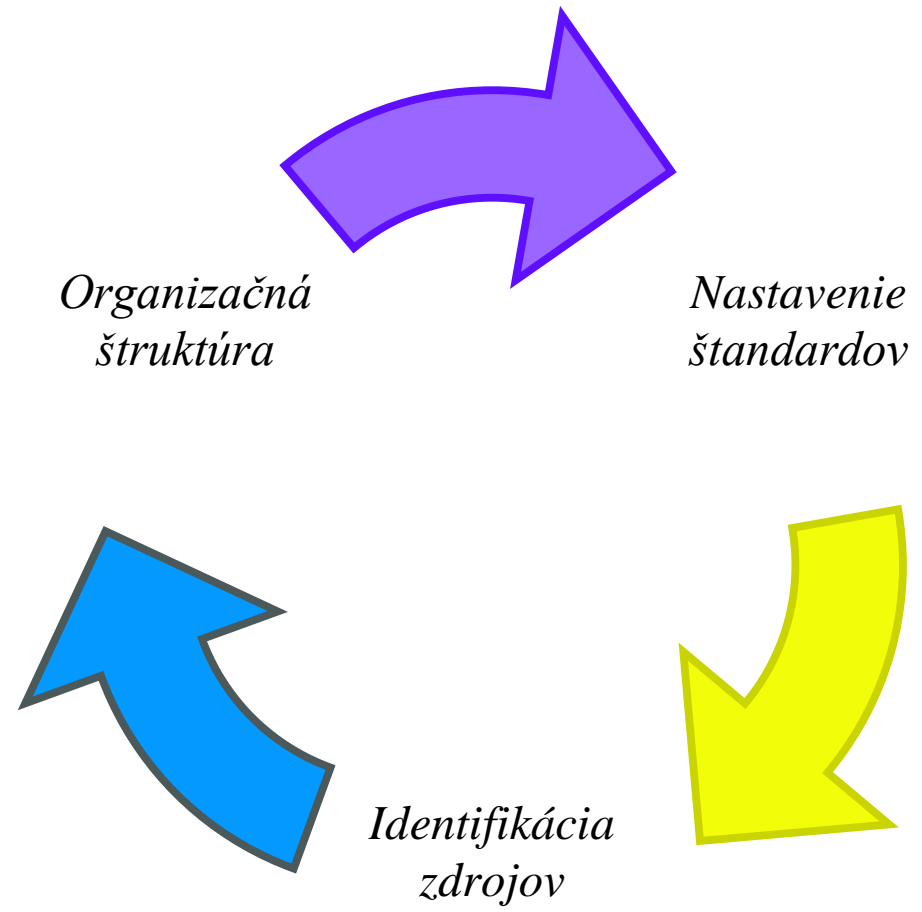

Obrázok 3. Organizácia virtuálneho tímu

(Zdroj: vlastné spracovanie) 


\section{Kontrola:}

Otázka kontroly je najväčším problémom virtuálneho manažmentu. Člen tímu pracujúci doma alebo na externom pracovisku majú vol'nost' pohybu a flexibilný pracovný čas, určenie ich výkonov je možné len na základe výsledkov, to pri niektorých typoch úloh je nemožné.

\section{Monitorovanie výkonov}

Sledovat' výkony pri virtuálnych tímov je zložité. Konečné výkony sú viditel'né, ale čiastkové prinášajú problémy. Manažér musí priebežne kontaktovat' jednotlivých členov tímu a zist'ovat' aké náročné sú jednotlivé úlohy. Pri tradičnom manažmente máme možnost' vizuálnej kontroly pracoviska, pri virtuálnej práci je vizuálna kontrola za bežných podmienok nemožná.

Každý problém má riešenie. Vhodná je metóda, pri ktorej člen tímu pracujúci externe sa loguje do systému, ktorý zaznamenáva jeho činnost' a sníma video záznam jeho práce cez web-kameru. Manažér má možnost' vizuálnej kontroly nielen priebežne, ale kedykol’vek.

\section{Vzdelávanie, odmeňovanie a disciplína}

Nájst' vhodnú alternatívu pre vzdelávanie pracovníkov na dial'ku je problematické z dôvodu absencie osobného kontaktu s lektormi. Je problematické udržat' disciplínu u pracovníkov, na ktorých nemáme priamy vplyv. Odmeňovanie ostáva nezmenené, používajú sa rovnaké metódy ako pri tradičnom manažmente.

Pri vzdelávaní je vhodné využívat' on-line služby, kde navrhujeme dve metódy:

- Metóda aktívnej účasti - metóda je vhodná v prípade ak manažér vie vytvorit' podmienky pre stretnutie všetkých zainteresovaných strán. Prednášky aj cvičenia sú vedené pomocou softvéru určeného na komunikáciu, (napr. skype) formou konferenčných hovorov.

- Metóda pasívnej účasti - vhodné využitie v prípade rozdielnych časových pásiem a nemožnosti zorganizovat' stretnutie všetkých zainteresovaných strán v jednom čase. Prednášky sa vložia dostupne na internet a cvičenia sú riešené formou úloh zrealizovaných do určitého času. Účastník kurzu má prístup k jednotlivým sekciám a učí sa v čase, ktorý je pre neho vyhovujúci. Manažér sa zbavuje povinnosti hl'adat' vhodný čas pre jednotlivých členov tímu. Pri virtuálnom tíme je vhodné využit’ práve formu pasívnej účasti.

\section{Komunikácia}

Komunikácia vo virtuálnom prostredí prebieha pomocou softvérou určených na komunikáciu. Prenos zvuku alebo obrazu dokážu zabezpečit' aj vol'ne dostupné softvéry, takzvané freeware.

Problém nastáva pre manažéra, ktorý pracuje z tímom z rôznych časových pásiem. Denný režim si musí prispôsobit' na základe jednotlivých členov tímu a musí vytvorit' harmonogram komunikácie. Ide o časový plán, ktorý zobrazuje jednotlivých členov tímu a ich dostupnost', pričom im vytvára možnost' komunikácie s manažérom a medzi sebou. Nastavovane harmonogramu komunikácie je zložitý proces, ktorý prebieha súčasne počas celého projektu. Je úlohou manažéra dohodnút' stretnutie člena tímu A s členom tímu B ak je to nutné.

\section{Spätná väzba}

Spätná väzba identifikuje problémy, ktoré počas projektu vznikli a zamedzuje ich d'alším vznikom v iných projektov. $\mathrm{Na}$ základe spätnej väzby sa manažér projektu stáva skúsenejším a vykonáva v projektoch menej chýb.

„,Múdry muž sa poučí s chýb iných, hlupák sa učí s vlastných. “ H. G. Wells

Podl'a vety Wellsa len hlupák robí chyby, ale aby sme sa vyhýbali chybám, niekto ju musí spravit' pred nami a následne ju zaznamenat'. Dôležitost' spätnej väzby je pozitívom pre všetkých manažérov, nielen pre manažéra daného projektu. 


\section{Riadenie}

Pri riadení virtuálneho tímu odpadávajú tím buildingové aktivity. Zorganizovat' tím building pre virtuálny tím je nákladné do neprínosnej miery. Dôraz sa kladie na building jednotlivcov. Manažér sa musí venovat' každému členovi tímu osobitne, pri vel'kých projektoch by dochádzalo k nedostatku času manažéra, preto je vhodné stanovit' si maximum možných pracovníkov pod manažérom, ktorých môže riadit'. Pri stanovení hodiny denne na pracovníka by manažér mohol riadit' až 24 podriadených denne, manažér je človek a musí oddychovat' a participovat' sa aj v iných odvetviach projektu. Odporúčanú hranicu podriadených sme stanovili na 6 u hlavného manažéra projektu. U sekundárnych, terciálnych a ostatných manažérov počet stanovujeme 3. Časové zat’aženie jednotlivých manažérov je približne rovnaké.

Hlavný manažér musí vhodne zvolit' podriadených pre jednotlivé sekcie. Geografické riešenie umožňuje kvalitnejšiu prácu, dôvody sú rovnaké ako pri tradičnom manažmente. Je lepšie, aby boli spolupracovníci $\mathrm{z}$ tej istej kancelárie $\mathrm{v}$ jednom tíme, ako keby bol každý pracovník v kancelárii v inom tíme. Pri virtuálnom tíme sú ako kancelárie brané jednotlivé oblasti (okresy, kraje, štáty, kontinenty).

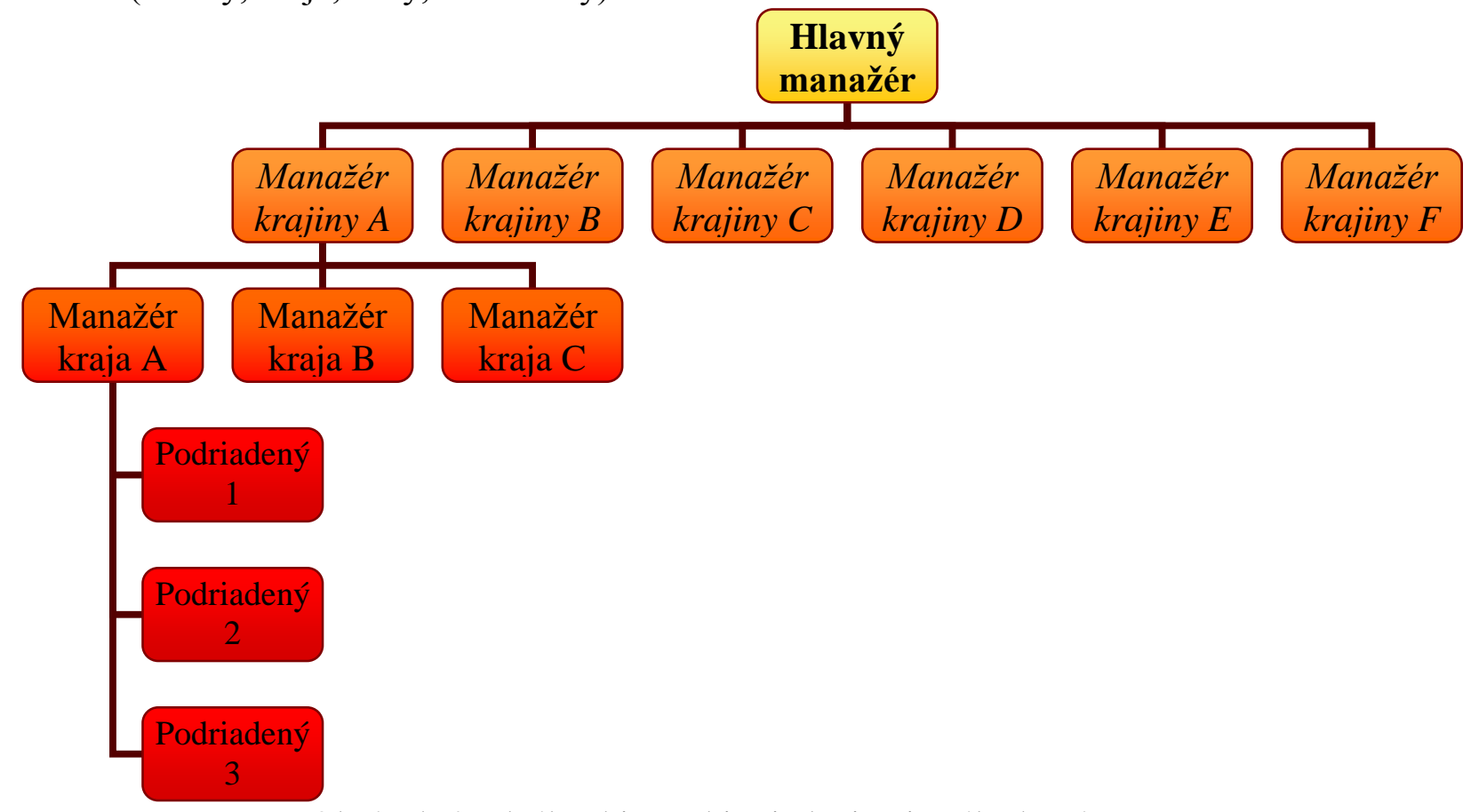

Obrázok 4. Ideálna hierarchia riadenia virtuálneho tímu (zdroj: vlastné spracovanie)

\section{Záver}

Môžeme poznamenat', že úspešný manažér virtuálneho projektového tímu musí mat' všetky vlastnosti tradičného manažéra, ale musí mat' aj vlastnosti potrebné pre fungovanie tímov na dial'ku. Stanovit' správne atribúty je t’ažká úloha, ktorá sa mení v závislosti od jednotlivých projektov. Projekt musí byt' jedinečný a aj prístup manažéra k projektu musí byt' unikátny. Virtuálny manažér by mal plánovat' jednotlivé činnosti až po vytvorení virtuálneho tímu. Nesmie zabúdat' na žiadnu zložku organizácie a kontrolu vykonávat' svedomito a v potrebný čas. Dôležité je poučit' sa z chýb svojich predchodcov. Manažér virtuálneho tímu by sa mal držat' pri vytváraní hierarchie a prerozdel'ovaní úloh systémom 6/3. 


\section{Literatúra}

[1] SVOZILOVÁ, Alena. 2006. Projektový management. Praha : Grada Publishing, a.s., 2006. ISBN 80-247-1501-5.

[2] KREMEŇOVÁ, Iveta a kol. 2009. Projektový manažment. Žilina: Žilinská univerzita v Žiline, 2009. ISBN 978-80-554-0148-5.

[3] CISCO [online] [s.a] [citované 2012-4-13]. Dostupné na internete: $<$ http://newsroom.cisco.com/>

[4] ELEFANT, RADOVAN. 2007. Manažérske komunikačné zručnosti a ich uplatňovanie $v$ riadení tímu $=$ Managerial communication skills and their exercitation in management team. Ostrava : Vysoká škola báňská, technická univerzita, in MEKON 2007. ISBN 978-80-248-1324-0.

\section{Grantová podpora:}

„Príspevok vznikol za podpory nasledovných grantových projektov:

VEGA 1/0199/11- Výskum interoperability metód riadenia so strategickým zámerom organizácie

KEGA 052ŽU-4/2012 On-line riadenie výučby v procese vzdelávania v oblasti IKT. 